\title{
Correction to: Water-pipe smoke condensate increases the internalization of Mycobacterium Bovis of type II alveolar epithelial cells (A549)
}

Esmaeil Mortaz ${ }^{1,2}$, Shamila D. Alipoor ${ }^{1,3,4}$, Masoud Movassaghi ${ }^{5^{*}}$, Mohammad Varahram ${ }^{6}$, Jahangir Ghorbani ${ }^{1}$, Gert Folkerts', Johan Garssen ${ }^{7,8}$ and lan M. Adcock ${ }^{9,10}$

Correction to: BMC Pulm Med 17, 68 (2017) https://doi.org/10.1186/s12890-017-0413-7

Following publication of the original article [1], the authors that there is an error in the FACs plots detailed in Fig. 4.

The error is that the plot of panel ' $\mathrm{C}$ ' has been duplicated as the plot of panel 'A'.

Please see the corrected figure in this correction article.

The authors apologize for any inconvenience caused.
${ }^{10}$ Priority Research Centre for Healthy Lungs, Hunter Medical Research Institute, The University of Newcastle, Newcastle, New South Wales, Australia.

Published online: 22 September 2020

Reference

1. Mortaz E, Alipoor SD, Movassaghi M, et al. Water-pipe smoke condensate increases the internalization of Mycobacterium Bovis of type II alveolar epithelial cells (A549). BMC Pulm Med. 2017;17:68. https://doi.org/10.1186/ s12890-017-0413-7.

\begin{abstract}
Author details
${ }^{1}$ Clinical Tuberculosis and Epidemiology Research Center, National Research Institute of Tuberculosis and Lung Diseases (NRITLD), Shahid Beheshti University of Medical Sciences, Tehran, Iran. ${ }^{2}$ Department of Immunology, Faculty of Medicine, Shahid Beheshti University of Medical Sciences, Tehran, Iran. ${ }^{3}$ Molecular Medicine Department, Institute of Medical Biotechnology, National Institute of Genetic Engineering and Biotechnology (NIGEB), Tehran, Iran. ${ }^{4}$ Department of Biotechnology, School of Advanced Technologies in Medicine, Shahid Beheshti University of Medical Sciences, Tehran, Iran. ${ }^{5}$ Department of Pathology and Laboratory Medicine, University of California, Los Angeles (UCLA), Los Angeles, CA, USA. ${ }^{6}$ Mycobacteriology Research Center (MRC) National Research Institute of Tuberculosis and lung Diseases (NRITLD), Shahid Beheshti University of Medical Sciences, Tehran, Iran. ${ }^{7}$ Division of Pharmacology, Faculty of Science, Utrecht Institute for Pharmaceutical Sciences, Utrecht University, Utrecht, The Netherlands. ${ }^{8}$ Nutricia Research Centre for Specialized Nutrition, Utrecht, The Netherlands. ${ }^{9}$ Cell and Molecular Biology Group, Airways Disease Section, National Heart and Lung Institute, Imperial College London, Dovehouse Street, London, UK.
\end{abstract}

The original article can be found online at https://doi.org/10.1186/s12890017-0413-7.

* Correspondence: MMovassaghi@mednet.ucla.edu

${ }^{5}$ Department of Pathology and Laboratory Medicine, University of California, Los Angeles (UCLA), Los Angeles, CA, USA

Full list of author information is available at the end of the article

(C) The Author(s). 2020 Open Access This article is licensed under a Creative Commons Attribution 4.0 International License, which permits use, sharing, adaptation, distribution and reproduction in any medium or format, as long as you give appropriate credit to the original author(s) and the source, provide a link to the Creative Commons licence, and indicate if changes were made. The images or other third party material in this article are included in the article's Creative Commons licence, unless indicated otherwise in a credit line to the material. If material is not included in the article's Creative Commons licence and your intended use is not permitted by statutory regulation or exceeds the permitted use, you will need to obtain permission directly from the copyright holder. To view a copy of this licence, visit http://creativecommons.org/licenses/by/4.0/ The Creative Commons Public Domain Dedication waiver (http://creativecommons.org/publicdomain/zero/1.0/) applies to the data made available in this article, unless otherwise stated in a credit line to the data. 


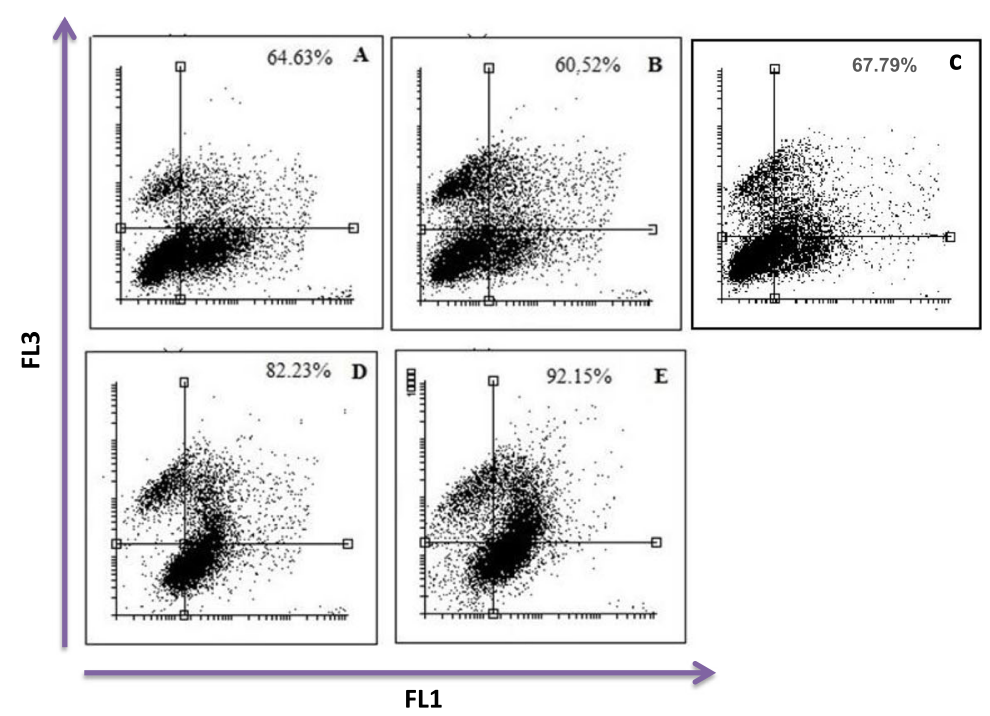

$\mathrm{F}$

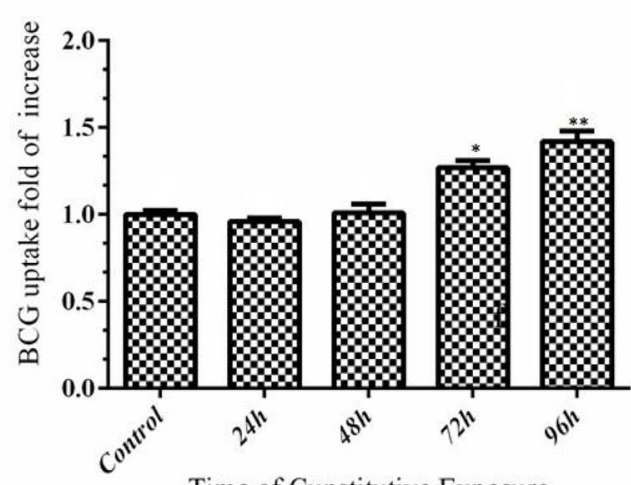

Time of Cunstitutive Exposure

Fig. 4 Time course of water pipe condensate (WPC) on the uptake of FITC-BCG. FITC-BCG uptake by A549 cells was increased in a timedependent manner compared to PBS-treated cells. Uptake was increased 1.3- and 1.4-fold after 72 and $96 \mathrm{~h}$ exposure to WPC, respectively while no effect on uptake was seen after 24 and 48 h on cells. a PBS control; b 24 h; c 48 h; d 72 h; and e 96 h exposure. Data are presented of three independent experiments. The data are presented graphically in (f) which shows the percentages of FITC-BCG positive cells at different time points in response to WPC compared to PBS exposure. PBS exposure had no effect on uptake and time course data are presented relative to PBS control. All dot and bars plots results are presented as mean \pm SD of the three independent experiments each repeated in triplicate. ${ }^{*} p<0.05$; ${ }^{* *} p<0.01$ versus control was calculated 